\title{
POLA CEDERA TORAKS PADA KECELAKAAN LALU LINTAS YANG MENYEBABKAN KEMATIAN DI BAGIAN FORENSIK DAN MEDIKOLEGAL RSUP PROF. Dr. R.D. KANDOU PERIODE JANUARI 2013- JANUARI 2014
}

\author{
Jessica R. Labora \\ Erwin G. Kristanto \\ James F. Siwu
Bagian Ilmu Kedokteran Forensik dan Medikolegal Fakultas Kedokteran
Universitas Sam Ratulangi - RSUP Prof. Dr. R. D. Kandou Manado
Email: jessicarefanya@yahoo.com

\begin{abstract}
Traffic accident is the most frequent cause of death. Chest injury is the third rank in traumatic cases due to traffic accident. This study aimed to obtain chest injury pattern due to traffic accident that led to death in the Forensic and Medicolegal Departement at Prof. Dr. R. D. Kandou Hospital Manado from Januari 2013 to Januari 2014. This was a retrospective descriptive study. Data were collected from the medical record of traffic accident cases. The results showed that there were 85 cases of traffic accidents during the time period, however, only 23 cases had visum et repertum. There were 7 death cases due to chest injuries. Their ages ranged from 17 to $>65$ years, mostly at the age of 17-25 years. Males were the most frequent $(71.43 \%)$. The most commonly found wounds were opened wounds and blisters (each was $28.58 \%$ ), followed by bruises and fractures (each was $14.28 \%$ ). Pattertns of left and right injuries of the chest did not differ much. Most victims were drivers (42.8\%). Conclusion: Chest injuries that led to deaths were more frequent among drivers, males, and aged 17-25 years.
\end{abstract}

Keywords: chest injury, traffic accident.

\begin{abstract}
Abstrak: Kecelakaan lalu lintas (KLL) masih menjadi salah satu penyebab utama kematian dengan angka kejadian yang cukup tinggi. Cedera toraks menduduki peringkat ketiga terbanyak pada kasus trauma akibat kecelakaan lalu lintas. Penelitian ini bertujuan untuk mengetahui pola cedera toraks pada kecelakaan lalu lintas yang menyebabkan kematian di Bagian Forensik dan Medikolegal RSUP Prof. Dr. R. D. Kandou Manado periode Januari 2013-Januari 2014. Penelitian ini menggunakan metode deskriptif retrospektif. Data dikumpulkan dari rekam medik seluruh kasus kecelakaan lalu lintas di tahun 2013-2014. Hasil penelitian memperlihatkan dari 85 kasus korban KLL hanya 23 kasus yang dilakukan visum et repertum, dan terdapat 7 kasus yang meninggal dengan cedera toraks. Usia korban berkisar 17 sampai dengan $>65$ tahun, terbanyak pada usia 17-25 tahun serta jenis kelamin laki-laki $(71,43 \%)$. Pola luka yang tersering terjadi ialah luka terbuka dan luka lecet (masing-masing 28,58\%), diikuti oleh luka memar, dan patah tulang (masing-masing 14,28\%). Pola cedera pada toraks sebelah kiri dan kanan tidak banyak berbeda. Peran korban terutama sebagai pengemudi (42,8\%). Simpulan: Korban KLL dengan cedera toraks yang menyebabkan kematian paling banyak terjadi pada pengemudi, jenis kelamin laki-laki, dan berusia 17-25 tahun.
\end{abstract}

Kata kunci: cedera toraks, kecelakaan lalu lintas. 
Toraks adalah daerah pada tubuh manusia yang berada diantara leher dan perut (abdomen). Toraks dapat didefinisikan sebagai area yang dibatasi di superior oleh thoracic inlet dan inferior oleh thoracic outlet, dengan batas luar adalah dinding toraks yang disusun oleh tulang-tulang vertebra torakal, kosta, dan sternum, serta otot dan jaringan ikat. Pada rongga toraks terdapat paru-paru dan mediastinum. Mediastinum dibagi menjadi 3 bagian: superior, anterior, dan posterior. Mediastinum terletak di antara paru-paru kiri dan kanan dan merupakan daerah tempat organ-organ penting toraks selain paru-paru, yaitu: jantung, aorta, arteri pulmonalis, vena kava, esofagus, trakea. ${ }^{1,2}$

Cedera toraks adalah luka atau cedera akibat benda tajam atau tumpul yang mengenai rongga toraks dan dapat menyebabkan kerusakan baik dinding toraks maupun isi kavum toraks yang berlanjut sebagai keadaan gawat toraks akut. Bahaya utama berhubungan dengan cedera toraks biasanya berupa perdarahan dalam dan tusukan terhadap organ. ${ }^{3}$

Cedera toraks dapat meluas dari benjolan dan goresan yang relatif kecil menjadi cedera yang dapat menghancurkan jaringan dan organ di bawahnya atau terjadi trauma penetrasi. Cedera dapat berupa penetrasi atau tanpa penetrasi (tumpul). Cedera toraks penetrasi mungkin disebabkan oleh luka terbuka yang memberi kesempatan bagi udara atmosfir masuk ke permukaan pleura dan menganggu mekanisme ventilasi normal. Cedera tersebut dapat menyebabkan kerusakan serius bagi paru-paru, kavum pleura dan struktur toraks lainnya sehingga membatasi kemampuan jantung untuk memompa darah atau kemampuan paru untuk pertukaran udara dan oksigen darah. ${ }^{3}$

\section{PATOFISIOLOGI CEDERA TORAKS}

Patofisiologi cedera toraks meliputi: ${ }^{3,4}$

1. Perdarahan.

2. Kerusakan alveoli/jalan napas/ pleura sehingga udara keluar dari jalan napas.

3. Patah tulang iga: timbul rasa nyeri sehingga penderita tidak mau bernapas (terjadi gangguan ventilasi) dan tidak mau batuk (sekret/dahak terkumpul/ tidak bisa keluar). Selain itu dapat terjadi flail chest bila patah tulang iga jamak dan segmental (lebih dari 1 tempat).

4. Kompresi pada toraks dapat mengakibatkan terjadinya asfiksia traumatika.

5. Luka "menghisap" pada dinding dada yang menyebabkan paru mengempis/ kolaps.

Mekanisme trauma toraks meliputi: ${ }^{5,6}$

1. Akselerasi: Kerusakan yang terjadi merupakan akibat langsung dari penyebab trauma. Gaya perusak berbanding lurus dengan massa dan percepatan (akselerasi) sesuai dengan hukum Newton II. Kerusakan yang terjadi juga bergantung pada luas jaringan tubuh yang menerima gaya perusak dari trauma tersebut.

2. Deselerasi: Kerusakan terjadi akibat mekanisme deselerasi dari jaringan. Biasanya terjadi pada tubuh yang bergerak dan tiba-tiba terhenti akibat trauma. Kerusakan terjadi oleh karena pada saat trauma organ-organ dalam keadaan masih bergerak dan gaya yang merusak terjadi akibat tumbukan pada dinding toraks/rongga tubuh lain atau oleh karena tarikan dari jaringan pengikat organ tersebut.

3. Torsio dan rotasi: Gaya torsio dan rotasi yang terjadi umumnya diakibatkan oleh adanya deselerasi organorgan dalam yang sebagian strukturnya memiliki jaringan pengikat/terfiksasi.

4. Blast injury: Kerusakan jaringan terjadi tanpa adanya kontak langsung dengan penyebab trauma, sebagai contoh: ledakan kendaraan saat terjadi kecelakaan lalu lintas (KLL). Gaya merusak di terima oleh tubuh melalui penghantaran gelombang energi.

\section{HASIL PENELITIAN DAN BAHASAN}

Data yang diperoleh di Bagian 
Forensik dan Medikolegal RSUP Prof. Dr. Kandou Manado memperlihatkan jumlah kasus dan kematian akibat KLL pada periode Januari 2013-Januari 2014 ialah 85 kasus. Persentase per bulan berkisar 2,3515,29\% dengan rerata per bulan 7,69\%. Kasus terbanyak terjadi pada bulan Mei 2013 dan yang paling sedikit pada bulan Desember 2013 (Tabel 1).

Tabel 1. Angka kematian akibat kecelakaan lalu lintas periode Januari 2013- Januari 2014 yang di periksa menurut data di Bagian Forensik dan Medikolegal RSUP Prof. Dr. R.D Kandou Manado

\begin{tabular}{cccc}
\hline Tahun & Bulan & $\begin{array}{c}\text { Jumlah } \\
\text { kasus }\end{array}$ & \% \\
\hline 2013 & Januari & 4 & 4,70 \\
& Februari & 7 & 8,25 \\
& Maret & 5 & 5,89 \\
& April & 6 & 7,05 \\
& Mei & 13 & 15,29 \\
& Juni & 8 & 9,42 \\
& Juli & 8 & 9,42 \\
& Agustus & 6 & 7,05 \\
& September & 3 & 3,53 \\
& Oktober & 9 & 10,58 \\
Jumlah & November & 9 & 10,58 \\
& Desember & 2 & 2,35 \\
& Januari & 5 & 5,89 \\
& & 85 & 100 \\
\hline
\end{tabular}

Dari seluruh kasus yang masuk di bagian Forensik dan Medikolegal RSUO Prof. Dr. Kandou Manado periode Januari 2013-Januari 2014, umumnya kasus tersebut diminta oleh pihak penyidik untuk dilakukan pemeriksaan luar agar diperoleh data mengenai regio tubuh yang mengalami cedera serta kepentingan peradilan (Tabel 2). Hal ini sesuai dengan pasal $133 \mathrm{KUHP}$ ayat 1 yang menyatakan dalam hal penyidikan untuk kepentingan peradilan menangani seorang korban baik luka, keracunan, ataupun mati yang diduga karena peristiwa yang merupakan tindak pidana, ia berwenang mengajukan permintaan keterangan ahli kepada ahli kedokteran atau dokter atau ahli lainnya. ${ }^{7-9}$

Sesuai data pada Tabel 2, luka terbuka serta luka lecet mempunyai persentase yangsama banyak pada korban KLL. Luka lecet adalah luka dangkal terbuka yang menimbulkan perdarahan dan kerusakan ujung-ujung saraf di kulit. Luka tersebut banyak terjadi pada korban akibat KLL dengan ukuran yang cukup luas. Luka lecet dapat disebabkan karena faktor pengemudi serta faktor lingkungan jalan. Posisi serta keadaan jatuh korban saat terjadi KLL menentukan seberapa luas luka lecet yang dapat terjadi pada tubuh korban. ${ }^{10}$ Terjadinya luka lecet antara toraks sebelah kiri (57,14\%) dan kanan (42,86\%) tidak banyak berbeda. Hal ini dapat disebabkan selain posisi kecelakaan peran sebagai pengendara atau pengemudi sepeda motor serta orang yang dibonceng maupun pejalan kaki juga turut berpengaruh. ${ }^{11}$

Tabel 2. Distribusi gambaran dan lokasi luka pada korban kasus kecelakaan lalu lintas yang meninggal dengan cedera thoraks sesuai pola cedera berdasarkan data di Bagian Forensik dan Medikolegal RSUP Prof. Dr. Kandou Manado periode Januari 2013-Januari 2014

\begin{tabular}{lccccc}
\hline & $\begin{array}{c}\text { Luka } \\
\text { Terbuka }\end{array}$ & Luka Lecet & $\begin{array}{c}\text { Luka } \\
\text { Memar }\end{array}$ & $\begin{array}{c}\text { Patah } \\
\text { Tulang }\end{array}$ & Campuran \\
\hline Toraks kanan & 1 & 1 & - & - & - \\
Toraks kiri & 1 & - & 1 & 1 & 1 \\
$\begin{array}{l}\text { Gabungan toraks } \\
\text { kanan dan kiri }\end{array}$ & - & 1 & - & - & - \\
Jumlah kasus & 2 & 2 & 1 & 1 & 1 \\
$\%$ & 28,58 & 28,58 & 14,28 & 14,28 & 14,28 \\
\hline
\end{tabular}


Luka memar adalah luka yang disebabkan oleh benturan benda yang keras sehingga terjadi kerusakan pada jaringan lunak dan ruptur pada pembuluh darah. Pada korban KLL benturan yang terjadi biasanya disebabkan oleh benturan dengan stang stir di kendaraan bermotor. Selain luka memar, benturan yang terjadi dapat mengakibatkan perdarahan pada organ yang terdapat dalam toraks seperti jantung dan paru-paru. Benturan tersebut juga dapat mengakibatkan fraktur pada beberapa tulang toraks; yang tersering ialah fraktur pada tulang iga dan sternum. ${ }^{12}$

Data yang diperoleh memperlihatkan bahwa pola luka yang paling sering terjadi ialah luka terbuka khususnya luka lecet, luka memar dan patah tulang. Ketiga pola luka tersebut dapat menyebabkan kematian pada korban KLL, yang juga dipengaruhi oleh faktor pengemudi, lingkungan jalan, serta posisi saat terjadinya kecelakaan. ${ }^{10,12}$

Korban meninggal akibat KLL terbanyak ialah laki-laki (Tabel 3). Hal ini mungkin disebabkan karena populasi lakilaki yang mengendarai lebih besar dari perempuan. Selain itu, laki-laki dewasa dituntut untuk bekerja keras mencari nafkah diluar tempat tinggal sehingga lakilaki merupakan objek terbanyak dalam menggunakan jalan raya, mengendarai kendaraan bermotor, serta khususnya dalam berlalu lintas. KLL juga dapat terjadi karena dewasa ini banyak pengendara yang kurang berkonsentrasi, menggunakan telepon genggam, atau dalam keadaan mabuk. Hal-hal tersebut di atas dapat mendukung mengapa jenis kelamin lakilaki mempunyai risiko yang cukup tinggi untuk terjadinya KLL yang dapat menyebabkan kematian.

Data Tabel 4 menunjukkan bahwa korban KLL yang meninggal denga cedera toraks terbanyak pada usia 17-25 tahun (30,58\%). Usia tersebut merupakan usia remaja hingga dewasa muda yang masih bersekolah/kuliah dengan keinginan serta pengaruh dari luar yang cukup besar untuk dapat mencoba banyak hal baru termasuk dalam mengendarai kendaraan bermotor dengan cara yang salah.
Tabel 3. Jumlah korban meninggal dengan cedera toraks akibat kecelakaan lalu lintas berdasarkan jenis kelamin yang masuk di Bagian Forensik dan Medikolegal RSUP Prof. Dr. Kandou Manado periode Januari 2013Januari 2014

\begin{tabular}{lccc}
\hline Tahun & $\begin{array}{c}\text { Laki- } \\
\text { laki }\end{array}$ & Perempuan & $\begin{array}{c}\text { Tanpa } \\
\text { keterangan }\end{array}$ \\
\hline 2013 & 4 & 0 & 2 \\
2014 & 1 & 0 & 0 \\
Jumlah & 5 & 0 & 2 \\
$\%$ & 71,43 & 0 & 28,57 \\
\hline
\end{tabular}

Tabel 4. Jumlah korban meninggal dengan cedera toraks akibat kecelakaan lalu lintas berdasarkan usia yang masuk di Bagian Forensik dan Medikolegal RSUP Prof. Dr. Kandou Manado periode Januari 2013-Januari 2014

\begin{tabular}{ccc}
\hline $\begin{array}{c}\text { Usia } \\
\text { (Tahun) }\end{array}$ & Jumlah korban & \% \\
\hline 0-5 Tahun & - & 0 \\
6-11 Tahun & - & 0 \\
12-16 Tahun & - & 0 \\
17-25 Tahun & 3 & 42,8 \\
26-35 Tahun & 1 & 14,3 \\
36-45 Tahun & - & 0 \\
46- 55 Tahun & 1 & 14,3 \\
56-65 Tahun & - & 0 \\
>65 Tahun & 1 & 14,3 \\
Tanpa keterangan & 1 & 14,3 \\
\hline Jumlah & 7 & 100 \\
\hline
\end{tabular}

Tabel 5 menunjukkan bahwa peran sebagai pengemudi/pengendara merupakan korban paling banyak menyebabkan kematian pada kasus KLL yang terjadi. Dari 7 kasus korban yang meninggal dengan cedera toraks pada KLL, 3 (47,86\%) di antaranya merupakan pengemudi atau pengendara sepeda motor. Hal-hal tersebut dapat disebabkan oleh karena tidak menggunakan helm saat mengendarai kendaraan bermotor, tidak menggunakan sabuk pengaman dalam mengendarai kendaraan atau sebagai penumpang dalam mobil, dan juga tidak mematuhi rambu-rambu serta peraturan lalu lintas yang ada. ${ }^{12-14}$

Korban pejalan kaki juga menunjukkan 
angka yang cukup besar. Hal ini dapat disebabkan oleh pejalan kaki terkadang tidak berhati-hati saat menyeberangi jalan utama, tergesa-gesa saat menyeberang dan yang paling sering ialah menyeberang bukan pada jalur penyeberangan yang ada. Korban pejalan kaki yang meninggal dengan cedera toraks ini biasanya di sebabkan oleh karena arah tabrakan yang terjadi membuat korban terlempar cukup jauh dan mengakibatkan patahnya beberapa tulang di bagian toraks. ${ }^{12-14}$

Tabel 5. Jumlah korban meninggal dengan cedera toraks akibat kecelakaan lalu lintas berdasarkan peran korban semula dalam berlalu lintas sesuai data visum et repertum di Bagian Forensik dan Medikolegal RSUP Prof. Dr. Kandou Manado periode Januari 2013-Januari 2014

\begin{tabular}{lcc}
\hline \multicolumn{1}{c}{ Peran korban semula } & $\begin{array}{c}\text { Jumlah } \\
\text { kasus }\end{array}$ & $\mathbf{\%}$ \\
\hline $\begin{array}{l}\text { Pengemudi/pengendara } \\
\text { sepeda motor }\end{array}$ & 3 & 42,8 \\
Yang dibonceng sepeda & 1 & 14,3 \\
motor & & \\
Penumpang mobil & - & 0 \\
Pejalan kaki & 1 & 14,3 \\
Tanpa keterangan & 2 & 28,6 \\
Jumlah & 7 & 100 \\
\hline
\end{tabular}

Dalam lembar visum et repertum juga ditemukan kasus yang meninggal dengan cedera toraks tanpa keterangan mengenai peran korban sebelum terjadinya KLL. Biasanya ini disebabkan oleh karena korban ditemukan sudah tergeletak di pinggir atau tengah jalan sehingga saat dilakukan pertolongan tidak diketahui apakah korban merupakan pengemudi, penumpang, maupun pejalan kaki. ${ }^{15-19}$

\section{SIMPULAN}

Dari hasil penelitian ini dapat disimpulkan bahwa cedera toraks pada kecelakaan lalu lintas yang menyebabkan kematian di Bagian Forensik dan Medikolegal RSUP Prof. Dr. Kandou Manado periode Januari 2013-Januari 2014 terbanyak ditemukan pada jenis kelamin laki-laki, usia 17 hingga 25 tahun, dengan pola luka terbuka yaitu luka lecet dan luka memar. Peran korban tersering sebagai pengemudi mobil atau pengendara sepeda motor.

\section{SARAN}

1. Perlu disosialisasikan pengetahuan tentang peraturan rambu-rambu lalu lintas, penggunaan helm standar yang benar, keharusan penggunaan sabuk pengaman saat mengemudikan kendaraan, serta mengontrol kecepatan saat mengemudi dan mengendara sepeda motor di jalan raya.

2. Diharapkan pihak kepolisian lebih memperhatikan dalam pemberian Surat Izin Mengemudi sesuai persyaratan yang telah ada, pengawasan penggunaan sabuk pengaman dan penggunaan helm serta sanksi yang tegas jika melanggar peraturan.

3. Bagi pemerintah hendaknya memperhatikan kelayakan jalan raya

4. Mensosialisasikan pentingnya dilakukan autopsi untuk menemukan penyebab pasti dan untuk kepentingan peradilan

5. Orang tua diharapkan tetap melakukan pengawasan yang ketat bagi anak-anak dibawah umur untuk tidak mengendarai kendaraan bermotor

\section{DAFTAR PUSTAKA}

1. Newman WA. 2002. Kamus Kedokteran Dorland. Jakarta: EGC, 2002.

2. Lukitto P, Rachmad KB, Manuaba TW. Dinding thoraks dan pleura. In: Karnadihardja W, Sjamsuhidajat R, De Jong W, editors. Buku Ajar Ilmu Bedah. Jakarta: EGC; 2004 p. 4040-14.

3. Standar Pelayanan Medis RSUP DR. Sardjito, jilid 3 (Edisi 2). Yogyakarta: Medika Fakultas Kedokteran Universitas Gadjah Mada, 2000; p. 167-172

4. Sampurna B, Samsu Z, Siswaja TD. Peranan Ilmu Forensik dalam Penegakan Hukum. Jakarta: 2008; p. 120. ISBN 978-979-8697-02-9.

5. IKABI, ATLS, American College of 
Surgeon, edisi ke-6, tahun 1997. [cited 2014 Nov 23]. Available from: http: med/linux.blogspot.com/2008/06/traum a-thorax.html?m=1

6. Sjamsuhidajat R, De Jong W. Buku Ajar Bedah. Jakarta: Penerbit Buku Kedokteran EGC, 1995.

7. Budiyanto A, Widiatmaka W, Sudiono S, Mun'im TWA, Hertian SS, Sampurna B, et al. Ilmu Kedokteran Forensik. Jakarta: Bagian Kedokteran Forensik Fakultas Kedokteran Universitas Indonesia, 1997.

8. Afandi D. Visum et Repertum pada korban hidup. Jurnal Ilmu Kedokteran. 2009;3(2):79-84.

9. Sampurna B, Samsu Z. Peranan Ilmu Forensik dalam Penegakan Hukum. Jakarta: Pustaka Dwipar, 2003

10. Dahlan S. Ilmu Kedokteran Forensik. Semarang: Bagian Kedokteran Forensik Fakultas Kedokteran Universitas Diponegoro, 2000.

11. Peraturan Pemerintah Republik Indonesia nomor 43 tahun 1993 tentang prasarana dan lalu lintas jalan. [cited 2014 Nov 27]. Available from: http:/hubdat. dephub.go.id/peraturan-pemerintah/79pp-no-43-tahun-1993-tentangprasarana-dan-lalu-lintas-jalan

12. Abdul MI, Agung LT. Penerapan Ilmu
Kedokteran Forensik dalam Proses Penyidikan (Edisi Revisi). Jakarta: CV. Sagung Seto, 2008

13. Sjamsuhidajat R, De Jong W. Buku Ajar Ilmu Bedah (Edisi 2). Jakarta: EGC, 2004; p.93.

14. Knight B. Forensic Pathology (Second Edition). New York: Arnold, 1997; p. 276

15. Bagian Ilmu Kedokteran Forensik dan Medikolegal Fakultas Kedokteran Indonesia. Pedoman teknik pemeriksaan dan interpretasi luka dengan orientasi medikolegal atas kecederaan. Jakarta, 2005.

16. Amir A. Rangkaian Ilmu kedokteran Forensik (Edisi 2). Jakarta: Ramadhan, 2005.

17. Soekanto S, Herkutanto, Sampurna B. Visum et Repertum Teknik Penyusunan dan Pemberian. Jakarta: INDHILL-CO, 1987.

18. Dahlan S. Pembuatan Visum Et Repertum. Semarang: Badan Penerbit Universitas Diponegoro, 1999.

19. Herkutanto, Pusponegoro AD, Sudarmo S. Aplikasi trauma-related injury severity score (TRISS) untuk penetapan derajat luka dalam konteks medikolegal. J I Bedah Indonesia. 2005;33(2):37-43. 